\title{
The Integration of Mind Mapping Technique in Storytelling to Assist EFL Students in Mastering Speaking Skill
}

\author{
${ }^{* 1}$ Nizar Saputra, ${ }^{2}$ Muntasir \\ ${ }^{* 1}$ Universitas Malikussaleh, Indonesia, nizarsaputra5@ gmail.com \\ ${ }^{2}$ Politeknik Kutaraja, Indonesia, muntasir.sulaiman@ gmail.com
}

Submitted: 06/09/2021 Revised: 14/10/2021 Accepted: 11/11/2021

How to cite this article: Saputra, N., \& Muntasir. (2021). The integration of mind mapping technique in storytelling to assist EFL students in mastering speaking skill. International Journal of Education, Language and Religion. 3(2), 1-6. doi: 10.35308/ijelr.v3i2.4460

\begin{abstract}
This research investigates the effectiveness of mind mapping implementation in storytelling to improve students' speaking skills. This research was framed as an experimental method in which tests and interviews are used to analyze the data. The test consisted of pre-test and post-test, while the structured interview is used to find out students' perspectives toward using mind mapping in storytelling. The finding suggests a significant difference between students' speaking skills in retelling stories using mind mapping and without mind mapping. This difference could be seen from the distribution of the t-score, which is higher than the t-table. T-score is 6.8 , and the t-table is 1.7 . The research also suggests that the students considered the mind mapping technique an excellent and effective technique applied in storytelling to improve their speaking performance. Based on the result, the application of the Mind Mapping Technique in storytelling in teaching speaking skills can be one of effective ways to improve the student's speaking performance.
\end{abstract}

\section{Keywords}

mind mapping technique; storytelling; speaking skill

\section{Introduction}

Many challenges are associated with students' difficulties in mastering English speaking skills or English-speaking performance. Al-Roud (2016) highlighted those speaking difficulties include physiological, instructor, social, and linguistic domains. Further, Pablo-MaquidatoAl-roud (2021) shared a similar view with Al-roud (2016) who mentioned that one of the linguistic domains that are mostly connected with students' obstacles in speaking English is their difficulties in constructing sentences or ideas to convey the message. Another barrier mentioned by Irwan (2016) is that Indonesian English learners find it hard to carry on the information, especially in retelling stories or delivering the information obtained from the English texts. Therefore, it is essential for the language instructors to address this issue; one of the ways is by implementing a mind mapping technique to help students 
brainstorm or construct the idea obtained from the text before retelling them in the form of English oral performance.

Mind mapping technique refers to a technique developed by Tony Buzan. Buzan (2012) explained that Mind Mapping is a powerful tool for brainstorming, creative thinking, problem-solving, organizing of ideas, and of course, note-taking. Hence, mind mapping can be considered an important technique that helps to improve students' concentration on the topic, which leads to students' better performance in retelling stories. While storytelling, according to Julia (2015), can act as a learner-centered method that can assist the students in using the information and delivering the messages to others. Zuhriyah (2017) shared the same view as Lucarevschi (2016) stating that storytelling could help to enhance students' speaking skills by developing students' fluency, comprehension, vocabulary, and pronunciation. Furthermore, many studies have highlighted that Mind Mapping can be a great resource in brainstorming student speaking context. For example, Nasution (2020) conducted an action research study that showed that the application of the mind mapping technique had improved students' speaking performance in the class, which transformed speaking class to be more enjoyable, interesting, and attractive.

In addition to that, some other studies, like Ramadhani (2020), showed that the application of the mind mapping technique increased students' achievement in Speaking ability and their interest in using mind mapping as their preferred technique for mastering speaking skills. Another study conducted by Ferry (2017) shares a similar result to Sulastri (2020), which showed that mind mapping could improve students' speaking performance as students are prepared with their brainstorm ideas; as a result, they can maintain their fluency and confidence leading to better English oral performance. Therefore, based on the research mentioned above, the authors are interested in scrutinizing how using the mind mapping technique in storytelling can improve students' speaking skills. This research can provide or add value to previous research by analyzing its depth and focus on how mind mapping works to enhance EFL students' speaking skills.

\section{Method}

This study was framed through quantitative research and experimental design to prove that mind mapping can improve students' speaking skills in storytelling. According to Bryman (2016) and Goertzen (2017), quantitative analysis involves numerical data collection to investigate the relationship between theory and research. Through this approach, the writers intended to examine how the idea related to the Mind Mapping technique can be associated with storytelling to improve students' speaking skills. To investigate further, the authors applied an experimental design to scrutinize a cause-and-effect relationship between the variables. Sukardi (2003), similar to Alhamda (2018), demonstrates that quantitative empirical research enables researchers to explore the influence of one variable on the other one and the hypothesis of causal-effect connection.

The sample of this research consists of second-year students in Serambi Mekkah University Banda Aceh. The sample was divided into two groups, controlled and experimental groups. The controlled group refers to students who perform storytelling without being introduced to the mind mapping technique or perform using other techniques but mind mapping. In contrast, the experimental group refers to a group receiving treatment using a mind mapping technique to brainstorm ideas or information in their storytelling. Both controlled class and experimental class experienced pretest and post-test as one means of data collection. These tests were then analyzed to find the mean, standard deviation, and t score to determine whether or not there was a notable difference in using mind mapping in storytelling to develop students' speaking skills. Furthermore, the interview was used as another instrument to collect data. The researcher employed closed-ended questions to determine students' perceptions. According to Desai and Reimers (2019), employing closed-ended questions in an interview enables research participants to experience less social pressure to present information that researchers were investigating while still meeting the researcher's knowledge and expectations. 


\section{Results and Discussion \\ Description of the Research Results}

Table 1 Descriptive statistic of pre-test and post-test scores

\begin{tabular}{llll}
\hline Score & N & Mean & SD \\
\hline Pre-test score of Experimental Class & 30 & 60.63 & - \\
\hline Pre-test score of Controlled Class & 30 & 63.83 & - \\
\hline Post-test scores of Experimental Class & 30 & 74.10 & 7.03 \\
\hline Post-test scores of Controlled Class & 30 & 64.23 & 3.80 \\
\hline
\end{tabular}

Table 1 illustrates the pre-test and post-test scores of research participants in experimental class (EC) and controlled class (CC). From this table, It can be seen that the mean score of the EC pre-test was 60.63 , increased to 74.10 in post-test. From this trend, it can be understood that there was a 14.47 difference between the EC pre-test and the EC post-test. However, the mean score of CC pre-test and $\mathrm{CC}$ post-test did not show a considerable gap, merely 0.4 points, which could mean that there is no significant improvement in students' performance in CC. Therefore, considering the vast gap in mean score in EC, it could be concluded that the application of the mind mapping technique had enhanced students' performance in storytelling and improved their speaking ability.

In determining the hypothesis' acceptance or rejection, the researchers followed the criteria proposed by Sudjana (2006), who stated that Ho is accepted and Ha is rejected if $t$ - score is lower than t-table, and $\mathrm{Ho}$ is rejected and $\mathrm{Ha}$ is rejected is accepted if $\mathrm{t}$-score is higher than $\mathrm{t}$-table. From this perspective, it is observable in table 2 that the t-test score is 6,8 , and the standard of the t-table, using $\mathrm{db} 58$, is 1.7. Based on this, it can be understood that the t-score is higher than the t-table. Based on the result, the researchers conclude that the hypothesis was accepted because Ha was accepted. If Ha is accepted and Ho is rejected, this can be interpreted that there is a significant difference between students' speaking skills in storytelling by using mind mapping and without using the mind mapping technique.

Table 2 Independent sample t test

\begin{tabular}{llllll}
\hline Group & Mean & SD & t-test & $d b$ & t-table \\
\hline Experimental & 74.10 & 7.03 & 6.8 & 58 & 1.7 \\
\hline Control & 64.23 & 3.80 & & & \\
\hline
\end{tabular}

\section{Students' Perspective toward The Application of Mind Mapping Technique in Storytelling to Improve Their Speaking Skills}

The researchers interviewed ten students to investigate their perspectives toward using the mind mapping technique in storytelling to improve their speaking skills. Their responses are presented as in the table below:

Table 3. Students' perspective toward the use mind mapping in storytelling

\begin{tabular}{llc}
\hline No & Categories & Percentage \\
\hline 1 & Mind mapping is a familiar technique to the students & $60 \%$ \\
\hline
\end{tabular}




\begin{tabular}{lll}
\hline 2 & Mind mapping is preferred technique to be used brainstorm the idea & $90 \%$ \\
\hline 3 & Mind mapping helps students to brainstorm the idea of their speaking performance & $90 \%$ \\
\hline 4 & Mind Mapping technique promotes fun learning atmosphere & $80 \%$ \\
\hline 5 & Mind mapping is easy to draw & $70 \%$ \\
\hline 6 & Mind mapping is a suitable technique to be implemented in speaking class & $80 \%$ \\
\hline 7 & Mind mapping effectively assists to improve students' speaking performance & $80 \%$ \\
\hline 8 & $\begin{array}{l}\text { Mind mapping used in storytelling process helps to maintain students' fluency and } \\
\text { confidence }\end{array}$ & $80 \%$ \\
\hline
\end{tabular}

The sixty percent or the majority of students mentioned that they are familiar with this mind mapping technique, and some of them said they sometimes used it to take notes. Most students, $90 \%$, also mentioned that mind mapping is one of the preferred techniques to prepare students' ideas intended to convey. In addition, Numerous participants also confirm that mind mapping can promote a fun and enjoyable learning environment. They can creatively design their mind map with color and pictures to help them remember the information. This perspective is relevant to what Nasution (2020) stated that the integration of mind mapping technique into speaking class promotes students' creativity in designing their mind mapping, which helps to promote a fun, attractive learning atmosphere as they can express their creativity. Accordingly, the mind mapping technique is common and favored in preparing talks that can integrate into activities in speaking class, such as storytelling, that helps ignite fun and enjoyable learning experiences.

This research also found that mind mapping in storytelling can effectively help students prepare or brainstorm the idea that the students want to speak. This argument can be seen from students' responses that $90 \%$ of students agreed that the mind mapping technique assisted them with the brainstorming idea. This finding is supported by Ferry (2017) and Sulastri (2020), who highlighted that effective brainstorming is one of the benefits of mind mapping incorporation into a speaking class activity. Furthermore, $70 \%$ of students agreed that the mind map is easy to draw, which means that brainstorming ideas with the mind mapping technique is less time-consuming. These findings are in line with Çoban and Selçuk (2017) mentioned that mind mapping helps to improve students' productivity allowing free flow of ideas in a controlled setting leading to efficiency and less time consuming

Moreover, the finding also indicates that 80 percent of students agreed that the mind mapping technique is relevant to speaking class and improves their speaking performance. Zuhriyah (2017) demonstrates that the mind mapping techniques direct to better performance in speaking tasks because it empowers students to be more fluent and confident or well prepared before performing any speaking tasks, including storytelling. This finding also corroborates Anggraeni's (2014), Singapura's (2017), and Prayitno's (2019) early research that found a similar result that mind mapping technique incorporation into storytelling helps improve students' speaking ability. Accordingly, Integrating the mind mapping technique as a medium for brainstorming in speaking class can promote students' speaking performance.

\section{Conclusion}

The research confirmed that integrating mind mapping in storytelling to improve students' speaking skills could solve a speaking problem and improve their speaking task performance. Based on the result of the study, three conclusions can be drawn. First, the data shows that using mind mapping techniques 
in retelling stories could significantly improve the students' speaking skills. Students who actively use mind mapping techniques to prepare or brainstorm ideas offer a more convincing and better performance than other students. Second, students can be more engaged and productive while retelling the story with mind mapping techniques as they have adequate preparation for the topic they want to perform. Third, students are more enthusiastic and convinced due to the well-prepared speech, which resulted in the students enjoying the speaking activity. These conclusions can contribute to existing literature where teachers are suggested to consider using the mind mapping technique as one of the ways to boost students' storytelling performance.

This research was framed as an experimental study. Although it could prove the hypothesis that mind mapping represents a vital role in storytelling to promote students' speaking skills, the researchers recommended this research also will be framed into qualitative research in which the structure interviewed is employed to investigate the more profound perspectives of the research participants. In addition to that, the researchers feel that more focus should also be established on how storytelling can develop students' speaking skills. Therefore, further research on qualitative interviews is recommended, and how storytelling enhances students' speaking skills should be examined further.

\section{References}

Alhamda, S. (2018). Buku ajar metlit dan statistik. Deepublish.

Al-Roud, A. A. (2016). Problems of english speaking skill that university students encounter from their perspectives. Journal of Education, Society and Behavioural Science, 1-9.

Anggraeni, F. M. (2014). The effect of mind mapping technique towards the students' speaking ability at 7 th grade of SMPN 4 Bandar Lampung. International Conference on Education and Language (ICEL). (Vol. 2).

Buzan, T. (2002). How to mind map: The ultimate thinking tool that will change your life. London: Thorson.

Bryman, A. (2016). Social research methods. Oxford, UK: Oxford University Press.

Çoban, S., \& Selçuk, E. (2017). The effect of mind mapping technique on students' achievements in music lessons and on their attitudes towards the mind mapping technique. Egitim ve Bilim, 42(190).

Desai, S. C., \& Reimers, S. (2019). Comparing the use of open and closed questions for web-based measures of the continued-influence effect. Behavior Research Methods, 51(3), 1426-1440.

Ferry, F. K. (2017). Improving the students' speaking skill by using mind mapping technique at Universitas Bina Darma. ELTE Journal (Journal of English Language teaching \& Education), $5(1)$.

Goertzen, M. J. (2017). Introduction to quantitative research and data. Library Technology Reports, 53(4), 12-18. https://journals.ala.org/index.php/ltr/article/view/6325

Irwan, D. (2016). The effect of retelling story towards students' speaking ability. Raden Intan State Islamic University. http://ejournal.radenintan.ac.id/index.php/ENGEDU

Julia, H. T. (2015). Telling tales: Using storytelling to teach EFL kindergarten students in Taiwan. International Journal of Research Studies in Education, 4(4), 13-25. doi: 10.5861/ijrse.2015.848

Lucarevschi, C. R. (2016). The role of storytelling on language learning: A literature review. Working Papers of The Linguistics Circle, 26(1), 24-44.

Singapura, N. M. S. (2017). The use of mind mapping technique to improve students' speaking skill. (Doctoral dissertation, University of Muhammadiyah Malang). https://eprints.umm.ac.id/35799/

Nasution, D. S. (2020). Mind mapping to improve students' speaking skill. English education: English Journal for Teaching and Learning, 8(01), 1-12.

Prayitno, A. (2019). The use of mind mapping in teaching speaking at SMP Yimi Full Day School Gresik (Doctoral dissertation, Universitas Muhammadiyah Gresik).

http://eprints.umg.ac.id/855/2/CHAPTER\%20II.pdf 
Ramadhani, N. H. (2020). Using mind mapping method to increase students speaking ability. (Thesis). Universitas Muhammadiyah Makassar. Makassar.

https://digilibadmin.unismuh.ac.id/upload/10597-Full_Text.pdf

Sudjana. 2006. Metode statistik. Bandung: Tarsito.

Sulastri, S. (2020). Improving students' speaking skill by mind mapping strategy. Language-edu, 9(2)

Pabro-Maquidato, I. M. (2021). The experience of english-speaking anxiety and coping strategies: A transcendental phenomenological study. International Journal of TESOL \& Education, 1(2), 4564.

Zuhriyah, M. (2017). Storytelling to improve students' speaking skill. English Education: Jurnal Tadris Bahasa Inggris, 10(1), 119-134. 